\title{
EFFECT OF FERTILIZER-N APPLICATION AND SEED COATING WITH RHIZOBIAL INOCULANTS ON SOYBEAN YIELD IN EASTERN PARAGUAY ${ }^{(1)}$
}

\author{
Aki Kubota ${ }^{(2)}$, Kent Hoshiba ${ }^{(3)}$ \& Jorge Bordon ${ }^{(3)}$
}

\begin{abstract}
SUMMARY
Nitrogen removal in soybean grains at harvest may exceed biological $\mathrm{N}_{2}$ fixation, particularly if grain yields are as high as typically achieved on "Terra Rossa" soils of Eastern Paraguay. Applying N fertilizer or coating seeds with rhizobial inoculants that enhance nodulation may represent a way of balancing the $\mathbf{N}$ budget. However, the effects of such treatments appear to be highly sitespecific. The objective of this study was to examine the effects of $\mathrm{N}$ application (N) and rhizobial inoculation (I) on nodulation, $\mathrm{N}$ accumulation and soybean yields in Eastern Paraguay. Field experiments were conducted in two consecutive soybean seasons. Dry conditions in the first year delayed sowing and reduced plant number $\mathrm{m}^{-2}$ and pod number plant ${ }^{-1}$. Grain yields were generally below $2 \mathrm{t} \mathrm{ha}^{-1}$ but the $+\mathrm{N}+\mathrm{I}$ treatment increased yields by about $75 \%$. In the second year favorable conditions resulted in yields of around $4 \mathrm{t} \mathrm{ha}^{-1}$ and the treatments had no effect. Nitrogen accumulation was higher in the first year and could therefore not explain the observed yield differences between years and treatment combinations. The positive effect of the $+\mathrm{N}+\mathrm{I}$ treatment in year one was associated with a more rapid root growth which could have reduced susceptibility to intermittent drought stress. Nodule biomass decreased between flowering and pod setting stages in the $+I$ treatment whereas further increases in nodule biomass in the -I treatment may have led to competition for assimilates between nodules and developing pods. Based on these preliminary results we conclude that $\mathrm{N}$ application and seed inoculation can offer short-term benefits in unfavorable years without negative effects on yield in favorable years.
\end{abstract}

Index terms: Glycine max, inoculum, nitrogen, nodulation, rhizobium.

\footnotetext{
(1) This study was funded by the Japan International Cooperation Agency (JICA), Tokyo. Recebido para publicação em setembro de 2007 e aprovado em abril de 2008.

(2) Former expert of CETAPAR-JICA, Paraguay. Current address: Matsushiro 5-638-2, Tsukuba, Ibaraki, $305-0035$ Japan. E-mail: akikubota@yahoo.com

${ }^{(3)}$ CETAPAR-JICA, Ruta 7, km 45, Distrito Yguazu, Depto. Alto Paraná, Paraguay. E-mail: hoshibaken@yahoo.com
} 


\title{
RESUMO: EFEITO DA APLICAÇÃO DE FERTILIZANTE-NITROGENADO E DA INOCULAÇÃO DE SEMENTES COM RIZÓBIOS NO RENDIMENTO DA SOJA NO PARAGUAI ORIENTAL
}

\begin{abstract}
A remoção do $\mathrm{N}$ em grãos de soja na colheita pode exceder a fixação biológica do $\mathrm{N}_{2}$, particularmente se os rendimentos dos grãos forem tão elevados quanto os obtidos tipicamente nos solos "Terra Roxa" da região oriental do Paraguai. A aplicação do fertilizante nitrogenado ou a inoculação das sementes com rizóbios que estimulem a nodulação podem representar uma maneira de equilibrar o balanço de $N$, porém o efeito de tais tratamentos parece ser altamente específico do local. O objetivo deste estudo foi examinar os efeitos da aplicação do nitrogênio (N) e da inoculação com rizóbios (I) na nodulação, na acumulação de $N$ e nos rendimentos de soja sob condições da região oriental do Paraguai. A pesquisa em campo foi conduzida durante duas safras consecutivas de soja. As condições de seca ou estiagem no primeiro ano atrasaram a semeadura e reduziram o número de plantas por $\mathrm{m}^{2}$ e o número de vagens/planta. Os rendimentos de grãos foram geralmente inferiores a $2 t$ ha $^{-1}$; no entanto, o tratamento $+N+I$ aumentou o rendimento em aproximadamente $75 \%$. Nas condições favoráveis do segundo ano, os rendimentos foram em torno de $4 t \mathrm{ha}^{-1}$ e os tratamentos não tiveram nenhum efeito. A acumulação de $N$ foi mais elevada no primeiro ano e, portanto, não pôde explicar as diferenças observadas no rendimento entre anos e combinações de tratamentos. O efeito positivo do tratamento $+N+$ I no primeiro ano foi associado com o crescimento mais rápido da raiz, que poderia ter reduzido a suscetibilidade ao estresse hídrico intermitente. A biomasa dos nódulos diminuiu entre a floração e a maturação das vagens no tratamento $+I$, enquanto aumentos adicionais na biomasa dos nódulos no tratamento -I podem ter conduzido à competição pela assimilação entre nódulos e desenvolvimento das vagens. Com base nesses resultados preliminares, conclui-se que a aplicação de $\mathrm{N}$ e a inoculação da semente podem oferecer benefícios a curto prazo em anos desfavoráveis, sem apresentar efeitos negativos no rendimento em anos favoráveis.
\end{abstract}

Termos de indexação: Glycine max, inoculante, nitrogênio, nodulação, rizóbio.

\section{INTRODUCTION}

Soybean (Glycine max. [L.] Merr.) is the most important cash crop grown on the red clayey "Terra Rossa" soils of Eastern Paraguay and, due to a combination of favorable climate and high soil fertility, yields are among the highest in the world (FAO, 2004). Typically, soybean is grown in the summer intercropped with wheat in the winter. A no-tillage farming system was used for both crops. Under continuous no-till system, the bulk density and penetration resistance in "Terra Rossa" soils tend to increase (Kubota et al., 2005a). With high soil compaction it is possible that $\mathrm{N}$ fixation is reduced by insufficient oxygen supply to soybean roots and nodules (Voorhees et al., 1976). This poses the threat that soybean plants become increasingly dependent on soil- $\mathrm{N}$ rather in detriment of $\mathrm{N}_{2}$ fixation to satisfy their high $\mathrm{N}$ demand.

Several studies of $\mathrm{N}$ budgets in soybean-based systems reported that $\mathrm{N}$ removal at harvest may exceed biological fixation (Harper et al., 1989; Peoples \& Craswell, 1992; Vanotti \& Bundy, 1995). Vanotti \& Bundy (1995) further showed that soybean can stimulate microorganisms that enhance soil N mineralization. As a result soil $\mathrm{N}$ fertility can decline over years, particularly if yields are high and if a second winter crop such as wheat also exports a considerable amount of $\mathrm{N}$ (Kubota et al., 2005b). The combination of high rates of $\mathrm{N}$ removal with a potential reduction of biological $\mathrm{N}_{2}$ fixation due to soil compaction may make it necessary to balance $\mathrm{N}$ budgets, either through $\mathrm{N}$ fertilizer application or by enhancing nodulation and $\mathrm{N}_{2}$ fixation. However, no study has reported on the effect of $\mathrm{N}$ fertilization on soybean in Eastern Paraguay.

Most studies on the effect of fertilizer-N on soybean growth and $\mathrm{N}_{2}$ fixation by rhizobium conducted elsewhere concluded that fertilization reduces $\mathrm{N}$ fixation through a reduction in the number, weight and activity of nodules (Starling et al., 1998; Chen et al., 1992). However, this effect depended on a variety of factors such as amount of $\mathrm{N}$ applied and type of soil, climate, and farming system. A few studies showed that small amounts of starter-N applied at sowing could improve root growth and $\mathrm{N}$ uptake by soybean prior to full nodulation (Hardarson \& Zepata, 1984; Wani et al., 1995; Gulden \& Vessey, 1998). Furthermore, positive responses to $\mathrm{N}$ fertilization have been reported when soybean yields are affected by drought (Lyons \& Earley, 1952; Purcell \& King, 1996). 
Coating soybean seeds with rhizobial inoculants has been suggested as a way to improve $\mathrm{N}_{2}$ fixation (Dobereiner et al., 1995; Seneviratne et al., 2000) but the success of inoculation was found to be highly variable (Peoples \& Craswell, 1992). In Brazil, effects of starter $\mathrm{N}$ and rhizobial inoculation have been tested repeatedly. Starter N increased N accumulation in plants but grain yields usually remained unchanged. Inoculation increased soybean grain yields in the Cerrado region of Brazil by up to $750 \mathrm{~kg} \mathrm{ha}^{-1}$ (Coutinho et al., 1999). This positive effect has been confirmed in other studies and seed coating with inoculants is now being recommended as a standard practice for soybean growers in Brazil (Alves et al., 2003).

However, so far no study on the effect of $\mathrm{N}$ fertilization or inoculation on soybean has been reported for Eastern Paraguay and rhizobial inoculation is not yet a common practice among soybean growers of that region. The objective of this study was to examine the effect of starter- $\mathrm{N}$ and rhizobium inoculation on nodulation, $\mathrm{N}$ accumulation and soybean yield under the conditions of Eastern Paraguay.

\section{MATERIALS AND METHODS}

Field experiments were conducted in two soybean growing seasons between January 2000 and May 2001 at Centro Tecnologico Agropecuario en Paraguay (CETAPAR), an agricultural research and extension institute located in the Yguazú district of Eastern Paraguay. The soil in the field (S25 ${ }^{\circ} 27^{\prime} 22.8^{\prime}$ "W0 $55^{\circ} 02$ ' 42.3 ") is clayey, classified as Rhodic kandiudox according to the U.S. Taxonomy, but locally referred to as "Terra Rossa". Texture and other soil properties are shown in table 1. The plot had been used for soybean - wheat cropping under a notillage farming system for seven years. Before planting the wheat winter crop, a compound fertilizer was applied to the soil surface every year at a rate of $36 \mathrm{~kg} \mathrm{ha}^{-1} \mathrm{~N}$ and $92 \mathrm{~kg} \mathrm{ha}^{-1} \mathrm{P}$. No fertilizer was applied until soybean sowing prior to this study. Treatments were arranged in a split-plot design with three replicates with starter $\mathrm{N}$ application as the main plot $(\mathrm{N})$ and rhizobial inoculation as subplots (I). Soybean (Glycine max. [L.] Merr.) was planted in all plots after $\mathrm{N}$ application. The area of each subplot was $32 \mathrm{~m}^{2}$ (4 by $8 \mathrm{~m}$ ). A neighboring field plot was used in the second year.

$\mathrm{N}$ fertilizer was applied as urea at a rate of $50 \mathrm{~kg} \mathrm{ha}^{-1} \mathrm{~N}$ just before sowing. No other fertilizers were applied before planting soybean. Two commercial rhizobial inoculants with peat carrier were used in this study: 'Rizoplus Super' in the 1999/2000 growing season (3 $\mathrm{g} \mathrm{kg}^{-1}$ seeds), and 'Biomax' in 2000/2001 (2.5 g kg-1 seeds). 'Rizoplus Super' contains Bradyrhizobium japonicum while 'Biomax' contains Bradyrhizobium japonicum and Bradyrhizobium elkanni. The inoculants were mixed with seeds before sowing. Different inoculants had to be used due to their varying availability in the country.

In the untilled plots, seeds were mechanically sown $\left(55 \mathrm{~kg} \mathrm{ha}^{-1}\right)$ at a row spacing of $35 \mathrm{~cm}$. Planting and harvesting were timed according to weather conditions and grain maturity. A soybean cultivar suitable for late sowing (FT2001, indeterminate type) was used because dry conditions delayed sowing by six weeks in the 1999/2000 growing season. Seeds of FT2001 were sown on January 4 and harvested on May 23, 2000. In the second year, cultivar Aurora (determinate type) was sown on November 15, 2000 and harvested on March 29, 2001.

In 1999/2000, shoots and roots were sampled twice at the flowering stage (March 7,63 days after sowing; DAS) and at the pod-setting stage (April 3, 90 DAS). In 2000/2001, they were sampled three times at the 7-leaf stage (Dec. 20, 35 DAS), at flowering (January 17, 63 DAS) and at pod-setting (March 5, $110 \mathrm{DAS})$. At all sampling dates we sampled five continuous plants from the second row in each plot. Root samples were taken at a depth of $30 \mathrm{~cm}$ and nodules were removed by hand from the roots. All plant parts were oven-dried for $48 \mathrm{~h}$ at $60^{\circ} \mathrm{C}$ and weighed. Dried samples were ground to pass a $2 \mathrm{~mm}$ mesh for total $\mathrm{N}$ analysis. The ground samples were digested with $\mathrm{H}_{2} \mathrm{SO}_{4}$, and analyzed by the Kjeldahl

Table 1. Properties of the "Terra Rossa" soil at the experimental site (CETAPAR, Yguazú District, eastern Paraguay)

\begin{tabular}{|c|c|c|c|c|c|c|c|c|c|c|}
\hline \multirow[b]{2}{*}{ Depth } & \multicolumn{3}{|c|}{ Soil particle-size distribution } & \multirow[b]{2}{*}{ Texture $^{(1)}$} & \multirow[b]{2}{*}{$\begin{array}{c}\text { Soil } \\
\text { color }^{(2)}\end{array}$} & \multirow[b]{2}{*}{$\begin{array}{c}\text { Soil } \\
\text { density }\end{array}$} & \multirow[b]{2}{*}{$\begin{array}{c}\text { Penetration } \\
\text { resistance }\end{array}$} & \multirow[b]{2}{*}{$\begin{array}{c}\mathrm{pH} \\
\mathrm{H}_{2} \mathrm{O}\end{array}$} & \multirow[b]{2}{*}{$\operatorname{SOM}^{(3)}$} & \multirow[b]{2}{*}{ Total N } \\
\hline & $\begin{array}{c}\text { Sand } \\
2.0-0.05\end{array}$ & $\begin{array}{c}\text { Silt } \\
0.05-0.002\end{array}$ & $\begin{array}{c}\text { Clay } \\
<0.002 \mathrm{~mm}\end{array}$ & & & & & & & \\
\hline $\mathrm{cm}$ & 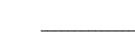 & $\%$ & 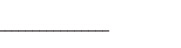 & & & $\mathrm{g} \mathrm{cm}^{-3}$ & $\mathrm{MPa}$ & & $-\mathrm{g} \mathrm{l}$ & - \\
\hline $0-5$ & 45.4 & 20.7 & 33.9 & Clay Loam & $2.5 \mathrm{YR} 3 / 3$ & 1.45 & 0.26 & 5.7 & 36.9 & 1.5 \\
\hline $5-15$ & 43.6 & 22.4 & 34.0 & Clay Loam & $2.5 \mathrm{YR} 3 / 3$ & 1.39 & 0.84 & 5.4 & 32.8 & 1.5 \\
\hline $15-30$ & 33.4 & 19.1 & 47.5 & Clay & 10R $3 / 3$ & 1.51 & 2.40 & 5.7 & 20.8 & 1.0 \\
\hline
\end{tabular}

(1) Classified by USDA system. ${ }^{(2)}$ Identified by the Munsell Soil Color Chart. ${ }^{(3)}$ Soil organic matter. 
method using an auto distillator (MRK-MATIC Auto Vapor-Still). At harvest, all above-ground dry matter was sampled from a $1 \mathrm{~m}^{2}$ area per plot.

All data were analyzed within each year representing split-plots, with the starter $\mathrm{N}$ treatment (N) as main factor and the inoculum treatment (I) as sub-factor. A set of linear contrasts was used to compare the $+\mathrm{N}+$ I treatment and means of other treatment combinations.

\section{RESULTS}

\section{Growing season 1999/2000}

The 1999/2000 season was abnormally dry during the regular sowing period (November) and again in March during flowering/early pod development (Figure 1). Due to the lack of rainfall in November 1999, planting was delayed by six weeks and an early pod setting cultivar, FT 2001 (indeterminate type), was used, suitable for late sowing.

At flowering shoot dry weight was not affected by treatments, whereas the combination of starter $\mathrm{N}$ with rhizobium inoculation $(+\mathrm{N}+\mathrm{I})$ significantly increased root dry weight (Table 2). Nodule weight responded positively to inoculation but at this early growth stage this did not increase $\mathrm{N}$ accumulation. At pod setting no significant difference was detected for root, shoot or nodule dry weight but while nodule weight more than doubled between flowering and pod setting stages in the -I treatment, nodule weight decreased by $28 \%$ in the $+\mathrm{I}$ treatment. Total $\mathrm{N}$ accumulation did not differ significantly between treatment combinations

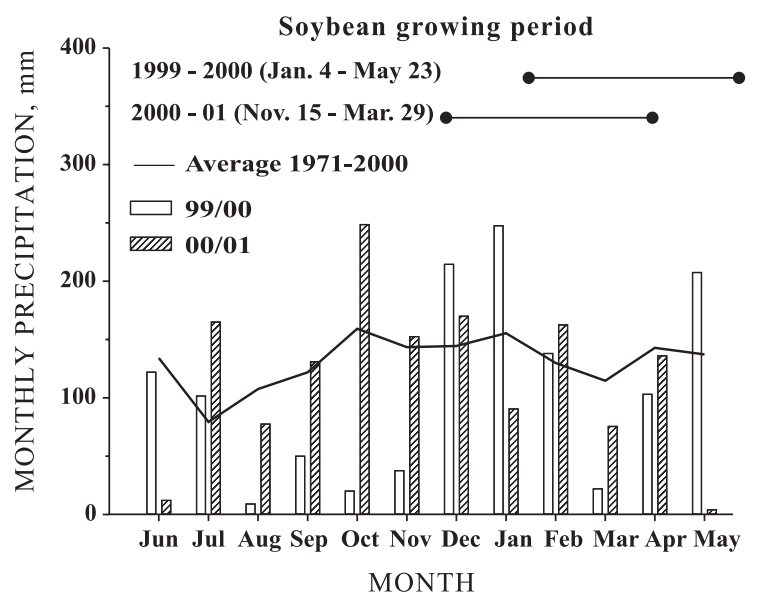

Figure 1. Monthly precipitation during the 1999/2000 and 2000/2001 growing seasons, compared to the 30 year average of CETAPAR.

but in the $+\mathrm{N}+$ I treatment significantly more $\mathrm{N}$ had been translocated to pods.

The grain yield in 1999/2000 was generally low but $\mathrm{N}$ application and seed inoculation had positive effects, and their combined application $(+\mathrm{N}+\mathrm{I})$ increased yield to about $3 \mathrm{t} \mathrm{ha}{ }^{-1}$, i.e., a $75 \%$ improvement over the other three treatment combinations (Table 3). A yield level of $3 \mathrm{t} \mathrm{ha}^{-1}$ is close to the average yield of the region (Seki, 1999). The $+\mathrm{N}+\mathrm{I}$ treatment tended to a higher plant density and higher pod number per plant than the other treatments (data not shown), and both factors probably contributed to the significantly higher grain yield. The harvest index (HI) was also highest in the + N + I treatment.

Table 2. Dry weight of soybean shoots, roots and nodules, and N accumulated at flowering stage (63 DAS, March 7), and at pod-setting stage (90 DAS, April 3) for the 1999/2000 growing season

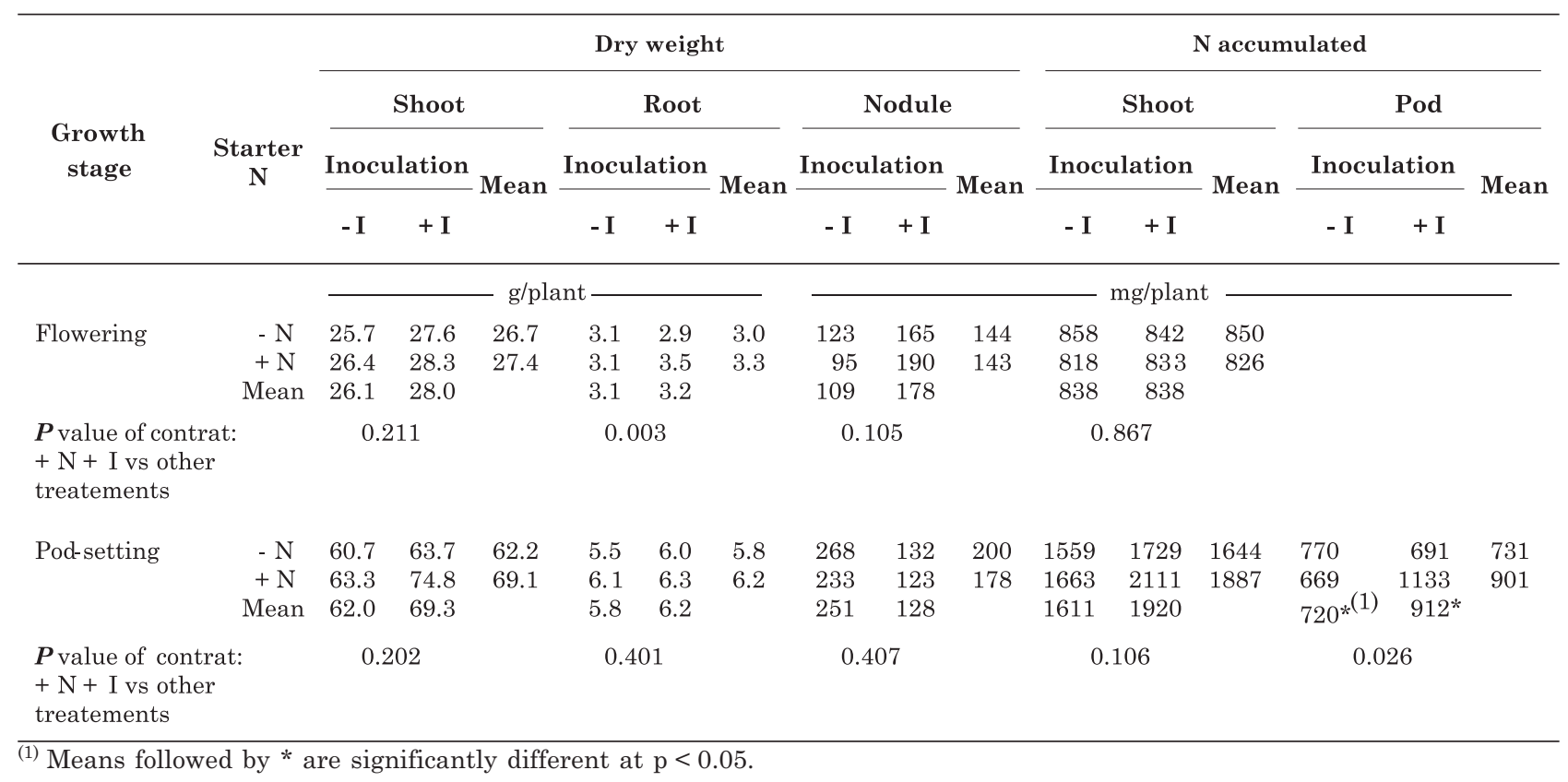




\section{Growing season 2000/2001}

The 2000/2001 season can be considered a typical year for the region with evenly distributed rainfall throughout the growing season (Figure 1). Sowing could be completed during the regular period in November and the locally preferred cultivar Aurora (determinate genotype, high yield potential) was used. In samples taken at the 7-leaf stage the $+\mathrm{N}$ treatment significantly increased shoot weight and $\mathrm{N}$ accumulation but nodule weight was reduced by more than $80 \%$ compared to the $-\mathrm{N}$ treatment (Table 4 ).
Soybean compensated these initial differences in later growth stages. No significant treatment effects for shoot or root dry weight were detected at flowering or pod setting. Unlike in the 1999/2000 growing season nodule weight increased throughout the season and reached a maximum at pod setting. However, at flowering nodule biomass was significantly higher in the inoculated plants. Grain yield in the 2000/2001 season was much higher than in year one and treatments had no significant effect on grain yield or yield components (Table 5).

Table 3. Soybean shoot dry weight, grain yield, 100-seed weight and harvest index for the 1999/2000 growing season

\begin{tabular}{|c|c|c|c|c|c|c|c|c|c|c|c|c|}
\hline \multirow{3}{*}{ Starter N } & \multicolumn{3}{|c|}{ Shoot dry wt. } & \multicolumn{3}{|c|}{ Grain yield } & \multicolumn{3}{|c|}{ 100-Seed wt. } & \multicolumn{3}{|c|}{ Harvest index } \\
\hline & \multicolumn{2}{|c|}{ Inoculation } & \multirow{2}{*}{ Mean } & \multicolumn{2}{|c|}{ Inoculation } & \multirow{2}{*}{ Mean } & \multicolumn{2}{|c|}{ Inoculation } & \multirow{2}{*}{ Mean } & \multicolumn{2}{|c|}{ Inoculation } & \multirow{2}{*}{ Mean } \\
\hline & $-I$ & $+I$ & & $-I$ & $+I$ & & $-I$ & $+I$ & & $-I$ & $+\mathbf{I}$ & \\
\hline & \multicolumn{6}{|c|}{ - kg ha ${ }^{-1}$} & 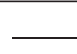 & $-\mathrm{g}-$ & - & & & \\
\hline$-\mathrm{N}$ & 7510 & 6530 & 7020 & 1750 & 1775 & 1763 & 11.5 & 10.3 & 10.9 & 0.23 & 0.27 & 0.25 \\
\hline$+\mathrm{N}$ & 6535 & 8925 & 7730 & 1640 & 3070 & 2355 & 9.1 & 10.5 & 9.8 & 0.25 & 0.34 & 0.30 \\
\hline Mean & 7023 & 7728 & & $1695^{*}(1)$ & $2423^{*}$ & & 10.3 & 10.4 & & 0.24 & 0.31 & \\
\hline $\begin{array}{l}\boldsymbol{P} \text { value of contrast: } \\
+\mathrm{N}+\mathrm{I} \text { vs. other } \\
\text { treatments }\end{array}$ & \multicolumn{2}{|c|}{0.086} & \multicolumn{4}{|c|}{0.005} & \multicolumn{2}{|c|}{0.891} & & \multicolumn{2}{|c|}{0.052} & \\
\hline
\end{tabular}

(1) Means followed by * are significantly different at $\mathrm{p}<0.05$.

Table 4. Dry weight of soybean shoots, roots and nodules, and N accumulated at 7-leaf stage (35 DAS, Dec. 20), flowering stage (63 DAS, January 17) and at pod-setting stage (110 DAS, March 5) for the 2000/2001 growing season

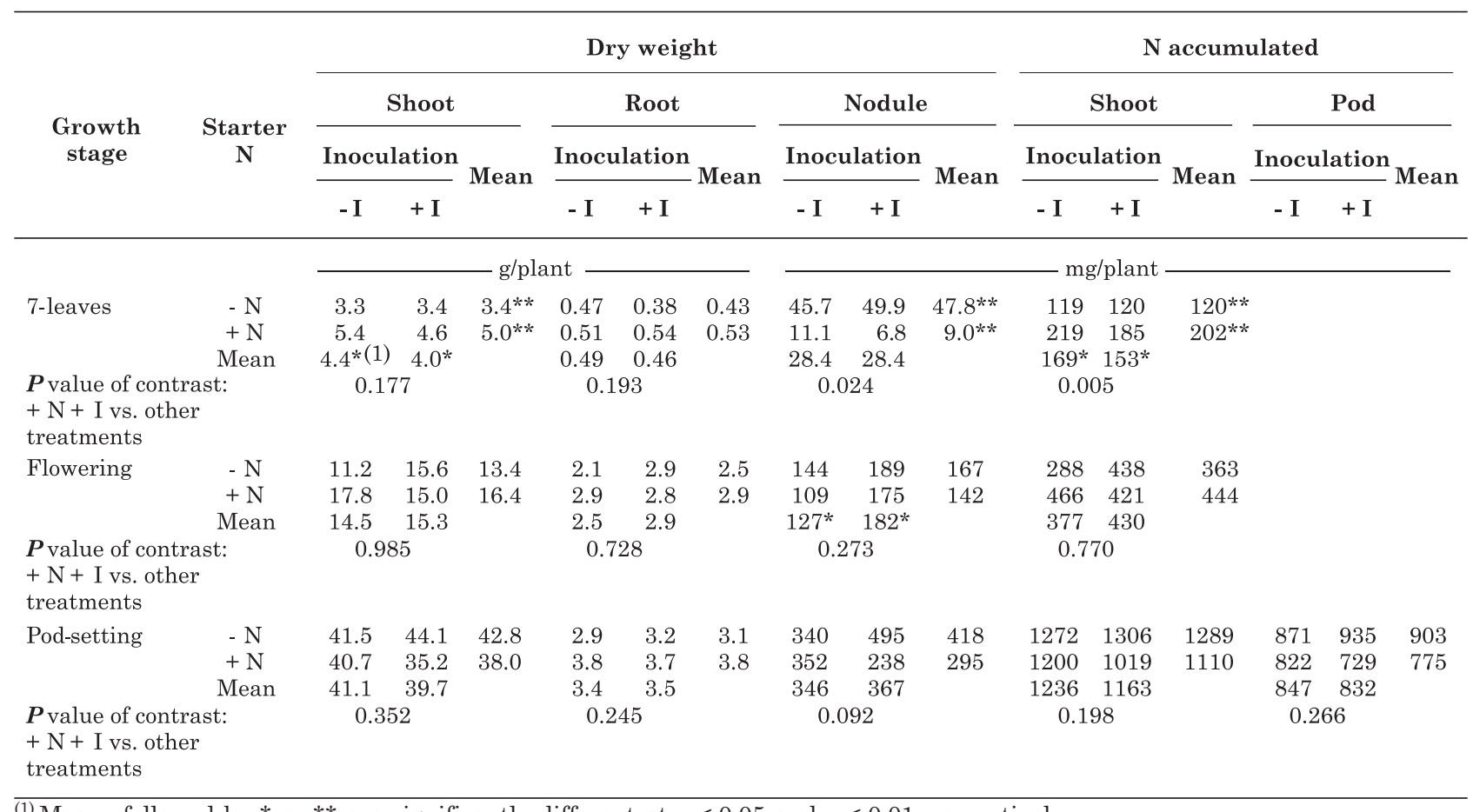

${ }^{(1)}$ Means followed by ${ }^{*}$ or ${ }^{* *}$ are significantly different at $\mathrm{p}<0.05$ and $\mathrm{p}<0.01$, respectively. 
Table 5. Soybean shoot dry weight, grain yield, 100-seed weight and harvest index for the 2000/2001 growing season

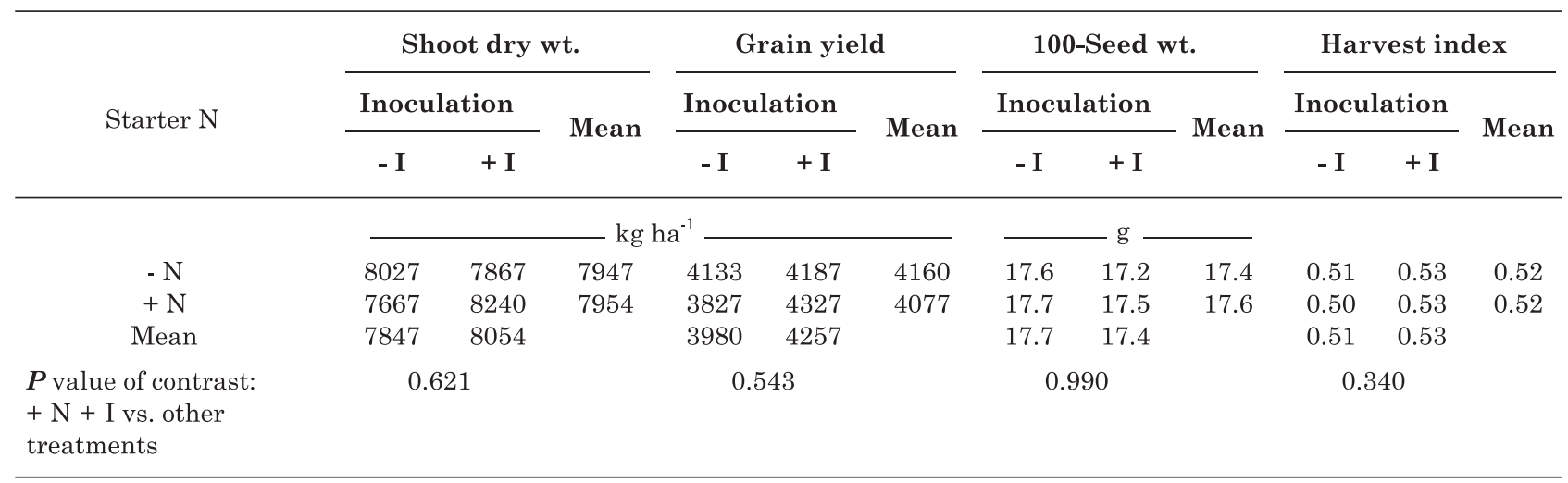

\section{DISCUSSION}

Benefits of inoculation and $\mathrm{N}$ application are generally thought to be higher if $\mathrm{N}$ is a limiting factor, either because of low $\mathrm{N}$ availability in the soil (Peoples \& Craswell, 1992) or because of large $\mathrm{N}$ demand of high yielding cultivars (Dashti et al., 1998). However, we could not confirm such a positive effect in the highly productive second year where estimated yields exceeded $4 \mathrm{t} \mathrm{ha}^{-1}$. Instead, benefits of the $+\mathrm{N}+\mathrm{I}$ treatment were detected in an unfavorable year when two factors, delayed sowing with an indeterminate genotype and an intermittent dry period during flowering/pod setting coincided, leading to reduced yields. A positive response to starter $\mathrm{N}$ application has been reported for each of these factors. Starling et al. (1998) showed that a starter application of $50 \mathrm{~kg} \mathrm{ha}{ }^{-1} \mathrm{~N}$ increased growth and grain yield of an indeterminate soybean type planted late. Sorensen \& Penas (1978) found in on-farm trials that sites with severe drought and low yields were most responsive to $\mathrm{N}$ fertilizer, while sites with high yield levels did not respond to N fertilizer. Similarly, Purcell \& King (1996) observed that $\mathrm{N}$ fertilizer application had no effect on irrigated plots but that drought-stressed soybean benefited from fertilizer $\mathrm{N}$ due to lower flower and pod abortion rates. They concluded that application of $\mathrm{N}$ fertilizer increased drought tolerance of soybean because of the extreme sensitivity of $\mathrm{N}_{2}$ fixation to drought.

Contrary to these observations $\mathrm{N}$ fertilization alone did not increase yields here. A positive effect of $\mathrm{N}$ application was only detected when seeds had been coated with rhizobial inoculants. This raises the question about the nature of additional benefits incurred by inoculation. Differences in soybean yields between years could not be explained by differences in $\mathrm{N}$ accumulation. On the contrary, high yields in the second year were achieved despite much lower total $\mathrm{N}$ accumulation at pod setting (Tables 2 and 4), indicating that $\mathrm{N}$ was probably not a yield limiting factor. It appears that soybean was able to satisfy $\mathrm{N}$ requirements without $\mathrm{N}$ application or inoculation on the "Terra Rossa" soil of the study area.

Based on our limited data set a possible explanation for the positive effect of inoculation in the 1999/2000 season could be linked to the sensitivity of soybean to water deficits during the flowering stage when plants typically react with flower abortion (Raper Jr. \& Kramer, 1987; Kokubun et al., 2001). Inoculated plants showed a slight reduction in nodule biomass between flowering and pod setting whereas nodule weight of plants in the-I treatment more than doubled during that period (Table 2). The increase of nodule biomass could have represented an additional stress factor for plants in the $-\mathrm{I}$ treatment as developing nodules are strong competitors for assimilates (Marschner, 1999). Negative effects on pod development are likely to increase if this competition between nodules and developing pods coincides with a water deficit. More detailed studies will be needed to confirm this hypothesis.

In addition to short-term and season-specific effects, $\mathrm{N}$ application could have some long-term benefits for the fact of adding $\mathrm{N}$ to a cropping system characterized by a negative $\mathrm{N}$ balance (Vanotti \& Bundy, 1995; Zotarelli et al., 2002; Kubota et al., 2005b).

\section{CONCLUSIONS}

1. No effect of $\mathrm{N}$ application or inoculation on grain yield was detected in a favorable year with high yields.

2. Starter $\mathrm{N}$ application together with seed coating with rhizobial inoculants is a viable option for delayed sowing.

3. The $+\mathrm{N}+$ I treatment combination appears to offer some protection against intermittent drought in the shortened growth period after delayed sowing. 


\section{ACKNOWLEDGEMENTS}

The assistance provided by Mr. Osamu Sato, Mrs. Aureliana Franco and Mr. Santiago Bogado is greatly appreciated.

\section{LITERATURE CITED}

ALVES, B.J.R.; BODDEY, R.M. \& URQUIAGA, S. The success of BNF in soybean in Brazil. Plant Soil, 252:1-9, 2003.

CHEN, Z.; MACKENZIE, A.F. \& FANOUS, M.A. Soybean nodulation and grain yield as influenced by $\mathrm{N}$-fertilizer rate, plant population density and cultivar in South Quebec. Can. J. Plant Sci., 72:1049-1056, 1992.

COUTINHO, H.L.C.; KAY, H.E.; MANFIO, G.P.; NAVES, M.C.P.; RIBEIRO, J.R.A.; RUMJANEK, N.G. \& BERINGER, J.E. Molecular evidence for shifts in polysaccharide composition associated with adaptation of soybean Bradyrhizobium strains to the Brazilian Cerrado soils. Environ. Microbiol., 1:401-408, 1999.

DASHTI, N.; ZHANG, F.; HYNES, R. \& SMITH, D.L. Plant growth promoting rhizobacteria accelerate nodulation and increase nitrogen fixation activity by field grown soybean [Glycine max (L.) Merr.] under short season conditions. Plant Soil, 200:205-213, 1998.

DOBEREINER, J.; URQUIAGA, S. \& BODDEY, R.M. Alternatives for nitrogen nutrition of crops in tropical agriculture. Fert. Res., 42:339-346, 1995.

FAO. Statistical Database, 2004 under: < http://faostat.fao.org>, Access date: July10, 2006.

GULDEN, R.H. \& VESSEY, J.K. Low concentrations of ammonium inhibit specific nodulation (nodule number $\mathrm{g}^{-1}$ root DW) in soybean (Glycine max [L.] Merr.). Plant Soil, 198:127-136, 1998

HARDARSON, G. \& ZEPATA, F. Effect of plant genotype and nitrogen fertilizer on symbiotic nitrogen fixation by soybean cultivars. Plant Soil, 82:397-405, 1984.

HARPER, L.A.; GIDDENS, J.E.; LANGDALE, G.W. \& SHARPE, R.R. Environmental effects on nitrogen dynamics in soybean under conservation and clean tillage systems. Agron. J., 81:623-631, 1989.

KOKUBUN, M.; SHIMADA, S. \& TAKAHASHI, M. Flower abortion caused by preanthesis water deficit is not attributed to impairment of pollen in soybean. Crop Sci., 41:1517-1521, 2001.

KUBOTA, A.; BORDON, J.; HOSHIBA, K.; HORITA, T. \& OGAWA, K. Change in physical properties of "Terra Rossa" soils in Paraguay under no-tillage. Soil Sci. Soc. Am. J., 69:1448-1454, 2005a.
KUBOTA, A.; HOSHIBA, K. \& BORDON, J. Green-manure turnip for soybean based no-tillage farming systems in Eastern Paraguay. Sci. Agric., 62:150-158, 2005b.

LYONS, J.C. \& EARLEY, E.B. The effect of ammonium nitrate applications to field soils on nodulation, seed yield, and nitrogen and oil content of the seed of soybeans. Soil Sci. Am. Proc., 16:259-263, 1952.

MARSCHNER, H. Mineral nutrition of higher plants. 2.ed. London, Academic Press, 1999. p.209-212.

PEOPLES, M.B. \& CRASWELL, E.T. Biological nitrogen fixation: Investments, expectations and actual contributions to agriculture. Plant Soil, 141:13-39, 1992.

PURCELL, L.C. \& KING, C.A. Drought and nitrogen source effects on nitrogen nutrition, seed growth, and yield in soybean. J. Plant Nutr., 19:969-993, 1996.

RAPER Jr, C.D. \& KRAMER, P.J. Stress physiology. In: WILCOX, J.R., ed. Soybeans: Improvement, production, and uses. 2.ed. Madison, ASA/CSSA/SSSA, 1987. p.589641.

SENEVIRATNE, G.; van HOLM, L.H.J. \& EKANAYAKE, E.M.H.G.S. Agronomic benefits of rhizobial inoculant use over nitrogen fertilizer application in tropical soybean. Field Crops Res., 68:199-203, 2000.

SEKI, Y. Soybean production under no-tillage in Paraguay (1). Agric. Hortic., 74:1080-1084, 1999.

SORENSEN, R.C. \& PENAS, E.J. Nitrogen fertilization of soybeans. Agron. J., 70:213-216, 1978

STARLING, M.E.; WOOD, C.W. \& WEAVER, D.B. Starter nitrogen and growth habit effects on late-planted soybean. Agron. J., 90:658-662, 1998.

VANOTTI, M.B. \& BUNDY, L.G. Soybean effects on soil nitrogen availability in crop rotation. Agron. J., 87:676680, 1995 .

VOORHEES, W.B.; CARLSON, V.A. \& SENST, C.G. Soybean nodulation as affected by wheel traffic. Agron. J., 68:976979, 1976 .

WANI, S.P.; RUPELA, O.P. \& LEE, K.K. Sustainable agriculture in the semi-arid tropics through biological nitrogen-fixation in grain legumes. Plant Soil, 174:29-49, 1995.

ZOTARELLI, L.; TORRES, E.; BODDEY, R.M.; URQUAGA, S. \& ALVES, B.J.R. Role of legumes in the $\mathrm{N}$ economy of cereal production in crop rotations under conventional and no-tillage. In: WORLD CONGRESS OF SOIL SCIENCE, 17., LOCAL, 2002. Proceedings. Thailand, 2002. p.1-7. (Symposium, 59; Paper, 866) 